\title{
Assessment of the influence of limnological factors on the malacofauna of two major man made lakes in Zaria, Nigeria
}

\author{
I. M. K. GADZAMA* and N. J. MONDO
}

Department of Biological Sciences, Ahmadu Bello University Zaria, Nigeria.

*Corresponding author.E-mail: ibskatsallah@gmail.com;ibsmadu@yahoo.com

\begin{abstract}
A comparative survey of molluscs was carried out in two major man-made lakes, Bomo and Kubanni, in Zaria during the rainy and dry seasons of 2007 and 2008. This was done to determine the molluscan compositions as well as to assess the physicochemical factors that may influence the malacofauna of the two lakes. Four sampling stations were selected along a line transect across each lake for collection of aquatic molluscs and measurement of physicochemical factors. Living representatives of molluscs belonging to the indigenous families: Planorbidae; Biomphalaria pfefferi and Bulinus globosus: Hydrobiidae; Unionidae; Anodonta marginata, Viviparidae; Viviparus sp. and Thiaridae; Melanoides torulosa and M. maculata, were obtained with only Thiaridae and Unionidae occurring in both lakes. However, the family Hydrobiidae was absent in Kubanni lake while Planorbidae and Viviparidae were absent in Bomo lake. Analysis of variance showed the seasonal variation of the physicochemical factors in the two lakes to be similar. The differences in the molluscan compositions of the two lakes could be attributed to other factors than variations in the physicochemical factors prevalent in the two lakes. This study has shown that considering their relative small sizes, Bomo and Kubanni lakes can be considered to have rich malacofauna of indigenous species, which can be targets for conservation initiatives and probable reservoirs of snail- hosts of diseases of public health significance.
\end{abstract}

(C) 2011 International Formulae Group. All rights reserved.

Keywords: Limnology, Freshwater molluscs, Distribution.

\section{INTRODUCTION}

Limnological studies on water bodies in West Africa have mainly focused on larger waters such as river Sokoto (Holden and Green, 1960), Lake Chad (Carmouze et al., 1983), the Volta river system (Bitney, 1990), Niger lakes (Segers et al., 1992) and Lake Kainji (Bidwell and Clarke, 1997). However, little attention is given to many smaller lakes and reservoirs around, whose study could contribute significantly to the understanding of tropical freshwater ecosystems and the impact of anthropogenic activities on them (Araoye, 2002). Since the 1930s, various detailed qualitative surveys have shown that total hardness, $\mathrm{pH}$, altitude, size of water bodies, temperature, vegetation and pollution were among the significant factors influencing the distribution and abundance of molluscs (Dillion, 2000). Eleutheradis and Lazaridou- 
Dimitriadou (1995b) reported that hardness and $\mathrm{pH}$ are the most important factors that both directly and indirectly influence metabolic activities and thereby growth and abundance of freshwater molluscs. Freshwater molluscs play the role of intermediate hosts for a great variety of human and animal parasitic flatworms (Chandler and Clark, 1961; Brown, 1994). Loker (2005) reported that, because of the massive scale of anticipated environmental change, studies to understand the basic ecology and ecological preferences of schistosome-transmitting snails remain critical. Molluscs are known to enhance maintenance of water purity in both fresh and ocean waters. Ajao and Fagade (2002) reported molluscs as indicators of organic pollution and other human induced stress factors in lagoons. This study therefore establishes the molluscan compositions in relation to critical environmental factors that influence the malacofauna of two major manmade lakes in Zaria.

\section{MATERIALS AND METHODS Study area}

Zaria lies in the northern Guinea Savanna zone of Nigeria, within $11^{\circ} 3 \mathrm{~N}, 7^{\circ}$ $42^{`}$ E. It is a region that has a Tropical Savanna climate with distinct wet (May to October) and dry (November to April) seasons (Happold, 1987). Zaria is characterized by mainly open woodland vegetation (Hore, 1970).

\section{Description of study lakes}

Bomo Lake is situated near a village called Bomo from which the name is derived. It is located on N1 $1^{\circ} 08.234^{\prime}$ and E007 $37.177^{\prime}$ with an elevation of $2234 \mathrm{ft}$ above sea level. The lake serves as a source of water for irrigation, domestic use by the villagers as well as for drinking by cattle. The bottom of the lake is sedimentation of silt, soft clay and organic matter.
Kubanni lake is located on $\mathrm{N} 11^{\circ} 08.234^{\prime}$ and E007 $39.345^{\prime}$ south of Ahmadu Bello University Zaria Samaru campus, with an elevation of $2111 \mathrm{ft}$ above sea level and reservoir area of $57 \mathrm{Km}^{2}$ and mean depth of 6 meters. The lake was impounded in 1972 and commissioned in 1982 with the aim of supplying water to the university community. The lake is characterized by seasonal variation in water level, which increases during the rains and drops considerably in the dry season, thereby exposing the littoral zone. The ground substrate is a mixture of sand and organic substrate.

The rains, between the months of May and October, serve as the major source of water to the two lakes. Both lakes are characterized by intensive fishing activities. Each lake is large enough to provide habitat that differ in substrate and other characteristics for various aquatic species. Dominant macrophytes include Azolla, water lily Nymphaea lotus and giant water lily Victoria regis.

\section{Collection and identification of molluscs}

Four different sites were selected at random and marked in a line transect along the shallow edges of each lake for collection of samples. Molluscs were collected using sweep net and picked by hand protected with disposable hand gloves. In the rainy season, collections were done before rainfall as a precaution against wash-off. Samples of molluscs collected were washed in water from the lakes and stored in $70 \%$ formalin in labeled plastic containers until identified. The height and breadth of the shells was measured using a sliding caliper. The number of whorls per mollusc was counted and the direction of the spiral coil of the shells noted. Molluscs were identified using guides by Horst (1965) and Thompson (2004). 


\section{Measurement and determination of habitat factors}

The longitude, latitude and elevation of the two lakes were measured using a Global Positioning System (Model N9: etrex®, Legend Garmin).

At each sampling station, the $\mathrm{pH}$, electrical conductivity, water temperature and total dissolved solids were measured using portable Combo Hanna ${ }^{\circledR}$ instrument (Model 98129). Water samples from the two lakes were collected at the points of collection of molluscs. Alkalinity, chloride, total hardness, biochemical oxygen demand (BOD) and dissolved oxygen (DO) were determined by titration, while colorimetric method was used to determine sulphate, phosphate and nitrate levels according to APHA (1989).

\section{Statistical analysis}

Analysis of variance (ANOVA) was used to determine the influence of the physicochemical parameters on the distribution of the aquatic molluscs during the four seasons in the two lakes. Analyse-it v.2.14 (Analyse-it, 2008) was used to determine and compare the relationships of the physicochemical parameters in the dry and rainy seasons, while Shapiro-Wilk method was used to assess the normality of the seasons.

\section{RESULTS}

Composition of freshwater molluscs of the lakes

Indigenous freshwater molluscs belonging to the families Planorbidae, Hydrobiidae, Thiaridae, Unionidae and Viviparidae were recorded in Kubanni and Bomo lakes (Table 1), with Thiaridae and Unionidae common to both lakes. However, the family Hydrobiidae was absent in Kubanni lake while Planorbidae and Viviparidae were absent in Bomo lake. A total of six species belonging to the genera Biomphalaria,
Bulinus, Anodonta, Viviparus and Melanoides were identified, with an unidentified hydrobid.

\section{Variability of freshwater parameters}

The seasonal variations of the physicochemical factors between the two lakes were not different $(\mathrm{P}>0.05)$. However, these factors were significantly different $(\mathrm{P}<0.05)$ in Bomo lake. The $\mathrm{pH}$, electrical conductivity, sulphate, alkalinity, dissolved oxygen and biochemical oxygen demand available for organisms were highest in the dry seasons in both Kubanni and Bomo lakes. Water temperature and phosphate phosphorus were highest during the rainy seasons in the two lakes. The total dissolved solids showed wide variations, with the highest mean value of $599 \pm 79.01 \mathrm{ppm}$ in the rainy season in Kubanni lake and lowest in Bomo lake in the same season with the mean value of $49 \pm 4.64$ ppm (Table 2). The average values of temperature for Kubanni and Bomo lakes were also higher in the rainy seasons than in the dry seasons with value of $26.8 \pm 0.07{ }^{\circ} \mathrm{C}$ and $25.4 \pm 0.65{ }^{\circ} \mathrm{C}$ respectively. The waters in the two lakes had an even total hardness.

The normality plots of the physicochemical factors for the four seasons in the two lakes (Figures 1-4) showed that the variability of the factors in the dry seasons have a similar pattern.

Significantly (confidence interval = 95\%) high positive and negative correlation values showing strength of relationships among the physicochemical factors of the two lakes was established (Table 3). Strong negative correlations existed between $\mathrm{pH}$ and temperature, sulphate, and phosphate phosphorus; electrical conductivity and temperature and sulphate. The relationships between electrical conductivity and nitrate, sulphate and phosphorus, BOD, DO and total hardness, and DO with chloride were highly positive. The TDS in the lakes showed highly significant positive correlation with electrical conductivity in the dry season. 
Table 1: Composition of molluscs in Bomo and Kubanni lakes.

\begin{tabular}{|c|c|c|}
\hline Family/Species & Bomo lake & Kubanni lake \\
\hline $\begin{array}{l}\text { Planorbidae: } \\
\text { Biomphalaria } \quad \text { pfefferi } \\
\text { Bulinus globosus }\end{array}$ & - & + \\
\hline $\begin{array}{l}\text { Hydrobiidae: } \\
\text { one species* }\end{array}$ & + & - \\
\hline $\begin{array}{l}\text { Thiaridae: } \\
\text { Melanoides torulosa and } \\
\text { M. maculata }\end{array}$ & + & + \\
\hline $\begin{array}{l}\text { Unionidae: } \\
\text { Anodonta marginata, }\end{array}$ & + & + \\
\hline $\begin{array}{l}\text { Viviparidae: } \\
\text { Viviparus } \mathrm{sp}\end{array}$ & - & + \\
\hline
\end{tabular}
$(-)=$ Absent,
$(+)=$ Present

Table 2: Combined mean values of physicochemical parameters of Bomo and Kubanni lakes during 2007 and 2008 seasons.

\begin{tabular}{llllc}
\hline Physiochemical & \multicolumn{2}{c}{ Bomo lake } & \multicolumn{2}{c}{ Kubanni lake } \\
\cline { 2 - 5 } parameters & Dry season & Rainy season & Dry season & Rainy season \\
\hline $\mathrm{pH}$ & $8.05 \pm 0.19$ & $7.05 \pm 0.07$ & $8.11 \pm 0.12$ & $7.21 \pm 0.12$ \\
Temperature $\left({ }^{\circ} \mathrm{C}\right)$ & $24.30 \pm 0.33$ & $26.80 \pm 0.07$ & $22.50 \pm 0.22$ & $25.40 \pm 0.65$ \\
Electrical conductivity $(\mu \mathrm{s} / \mathrm{cm})$ & $132 \pm 0.83$ & $86.30 \pm 3.09$ & $184 \pm 21.43$ & $85.00 \pm 16.01$ \\
Total dissolved solids $(\mathrm{ppm})$ & $66.00 \pm 0.41$ & $49.00 \pm 4.64$ & $94.0 \pm 11.74$ & $595 \pm 79.01$ \\
Dissolved oxygen $(\mathrm{mg} / \mathrm{L})$ & $17.11 \pm 0.62$ & $4.10 \pm 0.47$ & $4.20 \pm 0.12$ & $2.60 \pm 0.21$ \\
Biochemical oxygen demand $(\mathrm{mg} / \mathrm{L})$ & $10.11 \pm 0.71$ & $1.57 \pm 0.50$ & $1.58 \pm 0.06$ & $0.87 \pm 0.11$ \\
Chloride $(\mathrm{mg} / \mathrm{L})$ & $80.00 \pm 5.00$ & $31.78 \pm 1.65$ & $38.70 \pm .98$ & $39.00 \pm 2.01$ \\
Sulphate $(\mathrm{mg} / \mathrm{L})$ & $15.00 \pm 0.00$ & $75.04 \pm 6.34$ & $17.70 \pm 0.67$ & $80.00 \pm 2.30$ \\
Phosphate phosphorus $(\mathrm{mg} / \mathrm{L})$ & $78.57 \pm 21.43$ & $183.15 \pm 29.64$ & $150 \pm 12.10$ & $265 \pm 15.01$ \\
Nitrate $(\mathrm{mg} / \mathrm{L})$ & $1.10 \pm 0.10$ & $5.56 \pm 0.59$ & $13.00 \pm 0.63$ & $2.50 \pm 0.65$ \\
Total hardness & $40.00 \pm 0.05$ & $32.00 \pm 0.34$ & $33.30 \pm 0.00$ & $36.00 \pm 1.54$ \\
Alkalinity & $49.00 \pm 0.07$ & $28.50 \pm 0.09$ & $47.70 \pm 1.84$ & $29.70 \pm 0.26$ \\
\hline
\end{tabular}


I. M. K. GADZAMA and N. J. MONDO / Int. J. Biol. Chem. Sci. 5(5): 1898-1906, 2011

Table 3: Combined correlation matrix of the physicochemical parameters of Bomo and Kubanni lakes, Zaria.

\begin{tabular}{|c|c|c|c|c|c|c|c|c|c|c|c|c|}
\hline & pH & TEMP & EC & TDS & DO & BOD & $\begin{array}{l}\mathbf{C H} \\
\mathbf{L}\end{array}$ & SUL & $\begin{array}{l}\mathbf{P H} \\
\mathbf{O}\end{array}$ & NIT & $\begin{array}{l}\text { HD } \\
\mathbf{N}\end{array}$ & $\begin{array}{l}\text { AL } \\
\mathbf{K}\end{array}$ \\
\hline pH & 1 & & & & & & & & & & & \\
\hline TEMP & -0.91 & 1 & & & & & & & & & & \\
\hline EC & 0.90 & -0.95 & 1 & & & & & & & & & \\
\hline TDS & -0.42 & 0.17 & -0.46 & 1 & & & & & & & & \\
\hline DO & 0.57 & -0.19 & 0.20 & -0.44 & 1 & & & & & & & \\
\hline BOD & 0.56 & -0.18 & 0.18 & -0.41 & 1.00 & 1 & & & & & & \\
\hline CHL & 0.61 & -0.27 & 0.21 & -0.25 & 0.97 & 0.98 & 1 & & & & & \\
\hline SUL & -0.98 & 0.83 & -0.88 & 0.58 & -0.65 & -0.63 & -0.64 & 1 & & & & \\
\hline PHO & -0.75 & 0.41 & -0.56 & 0.82 & -0.84 & -0.82 & -0.75 & 0.85 & 1 & & & \\
\hline NIT & 0.34 & -0.58 & 0.71 & -0.33 & -0.49 & -0.51 & -0.53 & -0.31 & -0.03 & 1 & & \\
\hline HDN & 0.45 & -0.20 & 0.03 & 0.13 & 0.83 & 0.85 & 0.93 & -0.43 & -0.45 & -0.67 & 1 & \\
\hline ALK & 0.50 & -0.24 & 0.52 & -1.00 & 0.49 & 0.46 & 0.32 & -0.65 & -0.86 & 0.33 & -0.06 & 1 \\
\hline
\end{tabular}

TEMP- Temperature, EC- Electrical conductivity, TDS- Total dissolved solids, DO- Dissolved oxygen, BOD- Biochemical oxygen demand,

CHL- Chloride, SUL- Sulphate, PHO- Phosphate phosphorus, NIT- Nitrate, HDN- Total Hardness, ALK- Alkalinity. 

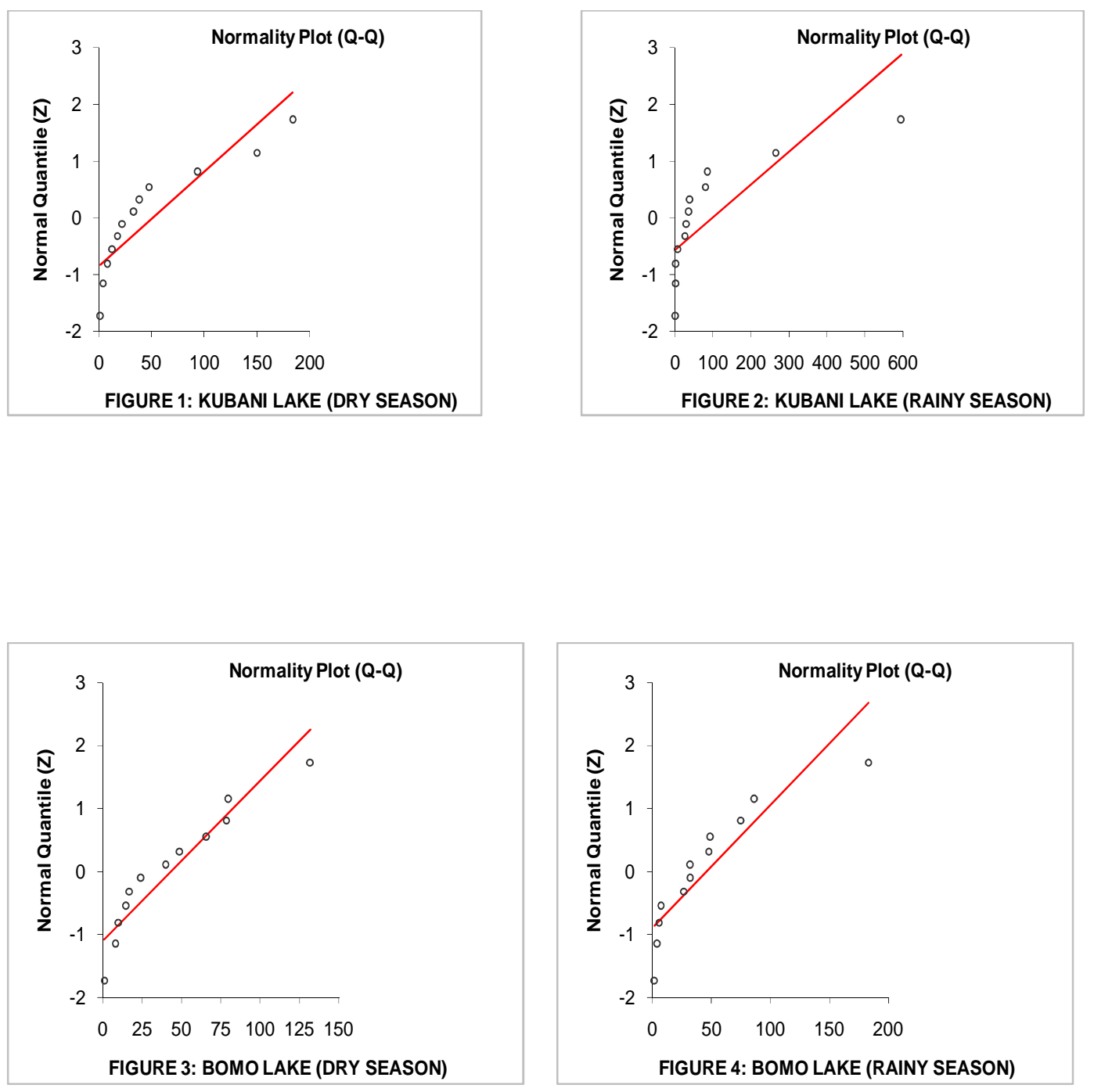

Figures 1- 4: Normality plots (Q-Q) of the seasonal variation of physicochemical factors in Bomo and Kubanni lakes.

\section{DISCUSSION}

The locations of the two lakes are sufficiently distinct from each other to result in colonization by different species of molluscs. The study has shown that Bomo and Kubanni lakes support a good number of molluscan families. Boycott (1936) reported that the needs of freshwater molluscs are so similar that habitats can be classified as good or bad for molluscs.
Analysis of variance showed the seasonal variation of the physicochemical factors in the two lakes to be similar. Higher values of $\mathrm{pH}$, electrical conductivity, dissolved oxygen and biochemical oxygen demands were observed during the dry season in Kubanni and Bomo lakes. The low DO and BOD in the rainy seasons reflects the high physical and biological processes in the lakes which constitute an indication of organic 
pollution. The high levels of electrical conductivity in the two lakes indicate the presence of large quantity of dissolved mineral salts (Trivedy and Goyal, 1986). Total dissolved solids (TDS) in both lakes were higher in the rainy seasons. The extremely high value of $599 \pm 79.01 \mu$ s in Kubanni Lake is an indication of high mixture of colloidal particles in the water body. The normality plots of the four seasons in the two lakes show the range of values in the dry season to be the true representative values of typical freshwater lakes. The variability of the physicochemical parameters in the rainy seasons could be as a result of enrichment of the lakes from ingress of rain water from surrounding farms after heavy down pour. Studies by Chatter Jee et al. (2008) showed $\mathrm{pH}$, total hardness, phosphate and chloride contents exhibited an almost identical seasonal impulse in a freshwater river. In an aquatic habitat, $\mathrm{pH}$ is a key environmental factor affecting molluscan distribution (Clement et al., 2006). Variation in $\mathrm{pH}$ of a water body may be affected by its exposure to the atmosphere, biological activities and temperature fluctuation (Adebowale et al., 2008; Kumar and Bahadur, 2009). The annual $\mathrm{pH}$ range (7.05 to 8.11$)$ in this study suggests a favourable condition for molluscs. Reservoirs are known to conserve the bulk of local freshwater malacofauna, (Clement et al., 2006) especially if they are maintained at near-neutral pH levels (i.e., 7.3) and contain large substrates (i.e., rocks). Low $\mathrm{pH}$ values of less than 6.0 were reported to be unfavourable for the growth of molluscs (Dussart, 1976).

The high concentration of chloride, sulphate and nitrate salts in the lakes is important for the metabolic activities in the molluscs. Saliu and Eruteya (2006) reported that phosphate, nitrate, sulphate and chloride salts, and metals such as calcium and iron influence the biodiversity of aquatic fauna.
The high alkalinity in the dry seasons increases the quantitative capacity of the lakes to neutralize acidic condition. This may improve the conduciveness of the environment for aquatic molluscs. However, increased dilution from rain water could be responsible for the low values observed in the rainy seasons. Russel-Hunter and Eversole (1976) reported on the importance of calcium salts in both food and water for the growth of the molluscan shell, which is largely controlled by genetic makeup. Saunders and Rung (1990) established a strong correlation between alkalinity and mean weight population in the bivalve Pisidium casertanum. The differences in the molluscan compositions of the two lakes could be attributed to other factors than variations in the physicochemical factors prevalent in the two lakes.

In conclusion, this study has shown that despite their relative small sizes, Bomo and Kubanni lakes can be considered to have rich malacofauna of indigenous species, which make the lakes good targets for conservation initiatives. The seasonal ranges of the physicochemical factors within the lakes may be considered within tolerant limits for molluscs. The presence of the genera Biomphalaria, Bulinus and Melanoides is an indication that these lakes harbour reservoir snail- hosts of diseases of public health significance.

\section{ACKNOWLEDGEMENTS}

The authors sincerely thank Mr. Orji Silvanus and Mr. Simeon Utenu of the Department of Biological Sciences, Ahmadu Bello University, Zaria, for their technical assistance.

\section{REFERENCES}

Adebowal KO, Agunbiade FO, Olu-Owolabi BI. 2008. Impacts of natural and anthropogenic multiple sources of 
pollution on environmental conditions of Ondo State coastal water Nigeria. EJEAFChe, 7(4): 2797-2811.

Ajao EA, Fagade SO. 2002. The benthic macro-infauna of Lagos Lagoon. The Zoologist, Volume 1(12): 1-15.

American Public Health Association (APHA). 1989. Standard methods for examination of water and wastewater. $20^{\text {th }}$ Edition. Published by American Water Works Association/ Water Environmental Federation, Washington D.C.

Araoye PA. 2002. Man-made lakes, ecological studies and conservation needs in Nigeria. Revista De Biologia Tropical, 50: $857-864$.

Bidwell A, Clarke NV. 1997. The invertebrate fauna of Lake Kainji, Nigeria. Nigerian Field, 42: 104-110.

Bitney CA. 1990. A review of some characteristics of freshwater and coastal ecosystem in Ghana. 20p.

Boycott AE. 1936. Pulmonates: Systematics, Evolution and Ecology (Vol. 2A). Academic Press: London; 50-335.

Brown DS. 1994. Freshwater Snails of Africa and their Medical Importance. Taylor and Francis Limited: London.

Carmouze JP, Durand JR, Leveque C. 1983. Lake Chad: Ecology and productivity of a shallow tropical ecosystem. Monog. Biol., 53: 22.

Chandler AC, Clark RP. 1961. Introduction to Parasitology. John Wiley and Sons: New York; 822.

Chatter Jee A, Jain M, Roy US, Kumar MS. 2008. Limnochemical factors influencing the seasonal population density, secondary production and Calcium-toTissues ration in the freshwater limpet Septaria lineata (Archaeogastropoda: neritidae). Turkish Journal of Zoology, 32: 2008 .

Clements R, Koh LP, Lee TM, Meier R, Li D. 2006. Importance of reservoirs for the conservation of freshwater molluscs in a tropical urban landscape. ELSEVIER Biological Conservation, 128: 136-146.

Dillon RT Jr. 2000. The Ecology of Freshwater Molluscs. Cambridge University Press: 509.

Dussart GBJ. 1976. The ecology of freshwater molluscs in North-West England in relation to water chemistry. Journal of Molluscan Studies, 42: 181-198.

Eleutheradis N, Lazaridou-Dimitriadou M. 1995b. Density and growth of freshwater snails Bithynia graeca and Viviparus contectus in relation to water chemistry in Serres, Northern Greece. Journal of Molluscan Studies, 61: 347-352.

General and Clinical Laboratory Analyses Software Version 2.14. 2008. Analyse-it software Limited, Leeds, England.

Happold DCD. 1987. The Mammals of Nigeria. Clerendon Press: Oxford; 402.

Holden MJ, Green J. 1960. The hydrology and plankton of River Sokoto. Journal of Animal Ecology, 29: 165-184.

Hore PN. 1970. Weather and climate of Zaria. In Zaria and Its Regions: Occasional Papers, Department of Geography. Ahmadu Bello University: Zaria, 3; 8-12.

Horst J. 1965. The Young Specialist Looks at Molluscs. Burke Publishing Company Ltd: London; 12-69.

Kumar A, Bahadur Y. 2009. Physicochemical studies on the pollution potential of river Kosi at Rampur (India). World Journal of Agricultural Sciences, 5(1): 01-04.

Loker ES. 2005. Research on the intermediate hosts for schistosomiasis: What are the priorities? Presentation to the Scientific Working Group on Schistosomiasis. World Health Organization, Geneva, Switzerland. pp 1-13.

Saliu JK, Eruteya OJ. 2006. Biodiversity of gutters in Lagos metropolis, Nigeria. 
Journal of Biological Sciences, 6(5): 936940.

Saunders JF, Rung GW. 1990. Species distributions and shell characteristics of Pisidium (Mollusca: Bivalvia) in the Colorado Front Range: the role of abiotic factors. Freshwater Biology, 24: 275-285.

Segers N, Nwandiro CS, Dumont HJ. 1992. Rotifers of some lakes in the flood plain of the River Niger: Faunal composition and diversity. Hydrobiologia, 250: 63-71.
Thompson FG. 2004. Identification Manual for the Freshwater Snails of Florida. University of Florida: Gainesville, Florida; 16-125.

Trivedy RK, Goyal PK. 1986. Chemical and Biological Methods for Water Pollution Studies. Enviro-Media: Karad, India; 334, 36-96. 